\title{
Leukocyte Immunoglobulin-Like Receptor Subfamily B Member 2
}

National Cancer Institute

\section{Source}

National Cancer Institute. Leukocyte Immunoglobulin-Like Receptor Subfamily B Member

2. NCl Thesaurus. Code C102795.

Leukocyte immunoglobulin-like receptor subfamily B member 2 (598 aa, $\sim 65 \mathrm{kDa}$ ) is encoded by the human LILRB2 gene. This protein is involved in the regulation of class I $\mathrm{MHC}$ antigen responses. 